\title{
金属粉末射出成形により作製した銅焼結体の諸特性に及ぼす マイクロ/ナノ粉末割合の影響*
}

\author{
西 數 和 明*1, 柿下健一*2, 田中茂雄*3
}

\author{
Effect of Micro/Nano Powder Ratio on the Properties of Copper \\ Sintered Parts Produced by Metal Injection Molding
}

\author{
Kazuaki NISHIYABU*4, Kenichi KAKISHITA and Shigeo TANAKA \\ ${ }^{* 4}$ Department of Mechanical Engineering, Faculty of Science and Engineering, Kinki University, \\ 3-4-1 Kowakae, Higashiosaka-shi, Osaka, 577-8502 Japan
}

\begin{abstract}
In microminiaturization of metal injection molding, the use of finer metal powders is one of solutions for improving the dimensional accuracy and surface roughness of sintered products. This study aims to investigate the effects of micro/nano powder ratio on the properties of sintered parts in $\mu$-MIM process. A novel experimental machine which can achieve to mold without pelletizing was used to produce the tiny specimens with high trial efficiency and a small amount of feedstock. Small dumbbell specimens were produced with changing the binder content and the fraction of micro/nano copper powders. The effects of nano copper powder addition on the tap density of mixed powder, the viscosity of MIM feedstock and the grain size, surface roughness and tensile strength of sintered parts were revealed.
\end{abstract}

Key Words: Metal Injection Molding, Micro MIM, Nano Powder, Copper, Hybrid Powder, Melt Viscosity, Grain Size, Surface Roughness, Tensile Strength

\section{1. 精㐯}

金属粉末射出成形 (Metal Injection Molding, MIM) は, $10 \mu \mathrm{m}$ から数 $\mu \mathrm{m}$ 程度の金属粉末に多量のバインダを 添加しこれらを混練した MIM 材料をプラスチック 射出成形と同様に金型人充填し，脱脂および㛙結を経 て高精度な金属部品を量産できる複合の製造法である. MIM は製品または構造体のサイズが $1 \mathrm{~mm}$ 以下のマイ クロ部品の製造が可能であり，多くのマイクロ部品が 本手法により製造される可能性を有している．著者ら は，MIM のマイクロ化は MIM の高品質化に基づく製 造技術であると位置つけけ, MIMのマイク口化に伴う各 工程での課題を克服するため，マイクロ金属粉末射出 成形 (Micro MIM, $\mu$-MIM) の研究を行ってきた ${ }^{1) ~}{ }^{3}$. とりわけ，マイクロ犠牲樹脂型インサート金属粉末射 出成形 (Micro Sacrificial Plastic Mold Insert MIM, $\mu$-SPiMIM) 法はマイクロ構造体の量産に適した製造法

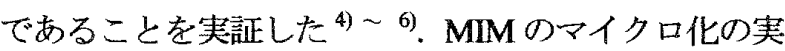

\footnotetext{
* 原稿受付 2009 年 9 月 8 日.

*1 正員, 近畿大学理工学部機械工学科(画577-8502 東大阪市 小若江 3-4-1) .

*2 前 : 大阪府立工業高等尃門学校專攻科。

*3 正員，太盛工業(株)（嫄572-0073 寝屋川市池田北町 26-1).

E-mail : nishiyabu@mech.kindai.ac.jp
}

現には，さらなる寸法精度の向上，型転写性および表 面平滑性が要求されるため，より粒径の小さい金属粉 末を使用寸ることが望まれる，しかし，粒径が小さく なると粉末の比表面積が増大し, MIM 材料の粘度が増 大し，射出成形が困難になる．加えて，サブ $\mu \mathrm{m}$ 以下 の超微粒子は酸化が著しく焼結が困難である ${ }^{1)}$.

本研究では，汎用の微粉末と超微粒子の複合化によ る相乗効果を探るため，粒径の異なる2 種類の純銅粉 およびバインダの配合割合を種々変化させた MIM 材 料の調製条件の決定方法を提案し，その溶融粘度の変 化や得られた焼結体の密度, 結晶粒径, 表面粗さや引 張強さに及ぼす影響を調查し，ナノ粉末を有効に利用 する $\mu$-MIM 製造法の可能性について調査した。

\section{2. 実険村料および方法}

2-1 使用材料使用材料は, 図 1 に示すように 粓径の異なる 2 種類の純銅粉とワックスおよびポリア セタール樹脂系バインダを混鍊した MIM材料である. レーザ回折式粒度分布測定装置（島津製作所㑣， SALD-7000）を用いて，純銅粉の粒度測定を行った結 果を図 2 に示す。この粒度分布から，サブ $\mu \mathrm{m}$ の銅粉 と数 $\mu \mathrm{m}$ のマイクロサイズの銅粉であることが分かる. 前者は高周波プラズマ法により製造された超微粒子 
（日清エンジニアリング㮫，BET 值より換算した粒径 $d_{B E T}=0.13 \mu \mathrm{m}$ ，ナ八銅粉と呼ぶ），後者は水アトマイズ 法により製造された MIM 用の粉末 (エプソンアトミ ックス侏，Pure Copper PF-15F，粒径 $d_{50}=8.2 \mu \mathrm{m}$ ，マイ クロ銅粉と呼ぶ) である.十ノ銅粉はマイク口銅粉に 比べて，比表面積が非常に大きく，粒子間の接触抵抗 が大きくなるため，嵩密度 (タップ密度) が低い，ま た, ナノ銅粉は図 1(a)の SEM 像では真球の単一粒子に なるように調製されているが，凝集しや寸く 2 次粒子 を形成しやすい，そのため，製粒時に凝集防止や安全 性等の理由から，特殊な樹脂が被覆されている.

\section{$2 \cdot 2$ ハイブリッド訜の充填本 マイクロ銅粉之} ナノ銅粉を異なるナノ銅粉割合 $(X)$ で混合した八イ ブリッド銅粉の充填率 $(f)$ をモデル化する，その際， 粉末形状を真球と仮定し, マイク口銅粉は平均粒径 $d_{50}$ ナノ銅粉は BET 值より換算した粒径 $d_{B E T}$ を用いた。 マ イクロ銅粉およびナノ銅粉のみ（X=0\%および $X=100 \%$ ）の場合の充填率をそれぞれ $f_{N}$ おひひ $f_{M}$ とす るとき，マイクロ銅粉間の隙間にナノ銅粉が理想的に 最密充填した場合のハイブリッド銅粉の最大充填率

$\left(f_{\text {max }}\right)$ は R.M.German により提案された 2 種の粒 径の異なる混合粉末の充填率の算出方法 ク上り, 式(1)で表される.

\begin{tabular}{|c|c|c|}
\hline & (a) $d_{B E T}=0.13 \mu \mathrm{m}$ & (d) $d_{50}=8.2 \mu \mathrm{m}$ \\
\hline \multicolumn{3}{|l|}{ SEM image } \\
\hline Oxygen Content & $4.670 \mathrm{wt.} \%$ & $0.061 \mathrm{wt} \%$ \\
\hline Carbon content & 0.060 wt.\% & 0.003 wt.\% \\
\hline $\begin{array}{c}\text { Tap density, } \\
\rho_{T A P}\end{array}$ & $0.66 \mathrm{~g} / \mathrm{cm}^{3}$ & $4.89 \mathrm{~g} / \mathrm{cm}^{3}$ \\
\hline $\begin{array}{c}\text { Specific surface } \\
\text { area }\end{array}$ & $5.10 \mathrm{~m}^{2} / \mathrm{g}$ & $0.10 \mathrm{~m}^{2} / \mathrm{g}$ \\
\hline
\end{tabular}

Fig. 1 Properties and SEM images of copper powders used

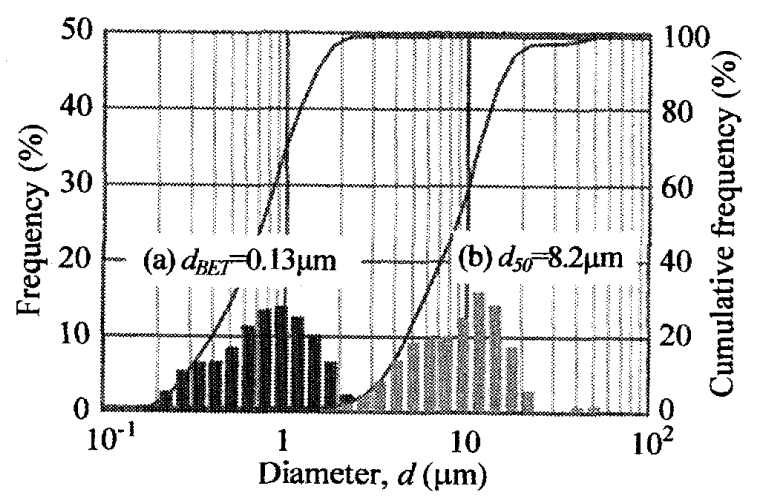

Fig. 2 Particle size distributions of copper powders used

$$
f_{\text {max }}=f_{M}+\left(1-f_{N}\right) f_{N} \quad \cdots \cdots \cdots \cdot(1)
$$

その際の十ノ銅粉割合 $\left(X^{*}\right)$ は式(2)で与えられる.

$$
X_{\text {max }}=f_{M} / f_{\text {max }}
$$

$X<X^{*}$ での充填率け式(3)で与えられる.

$$
f=f_{M} / X
$$

また， $X>X^{*}$ での充填率は式(3)で与えられる.

$$
f=f_{N} /\left(f_{N} X+1-X\right)
$$

ナノ銅粉の体積割合を変化させた場合のハイブリッド 銅粉の充填率を図 3 に示す，これは，マイクロ銅粉お よびナノ銅粉が面心立方構造に最密充填すると仮定し た計算值 (Closed pack) と上述の式(3)および式(4)より 求めた計算值 (R.M.German) に加え, プレス圧 9.8MPa での圧粉密度（Press (9.8MPa)) とタップ密度（Tap） の測定値を併せて示した図である.ここで，最密充填 すると仮定して充填率を算出する場合はナノ銅粉およ びマイク口銅粉の面心立方構造の最密充填率 $\left(f_{N}=f_{M}=73.8 \%\right)$ を用い，R.M.German により提案さ れた混合粉末の充填率を算出する場合はナノ銅粉 およびマイクロ銅粉のタップ密度を純銅の真密度で除 した充填率 $\left(f_{N}=7.33 \%\right.$ おび $\left.f_{M}=54.8 \%\right)$ を用いた。 その結果，最密充填すると仮定して算出した充填率の 場合は $X=20.6 \%$ で, R.M.German により提案された 混合粉末の充填率の場合は $X=5.71 \%$ ，それぞれ八 イブリッド銅粉の充填率にピークが見られた。これは ナノ銅粉の体積割合が増加するにつれて，マイクロ銅 粉の隙間にナノ銅粉が配置するためハイブリッド銅粉 の充填率は増加するが，その隙間にナノ銅粉が最密充 填する量を超えてナノ銅粉を添加すると，マイクロ銅 粉が最密充填しなくなり， ハブリッド銅粉の充填率 が低下寸るためである，一方，圧粉密度およびタップ

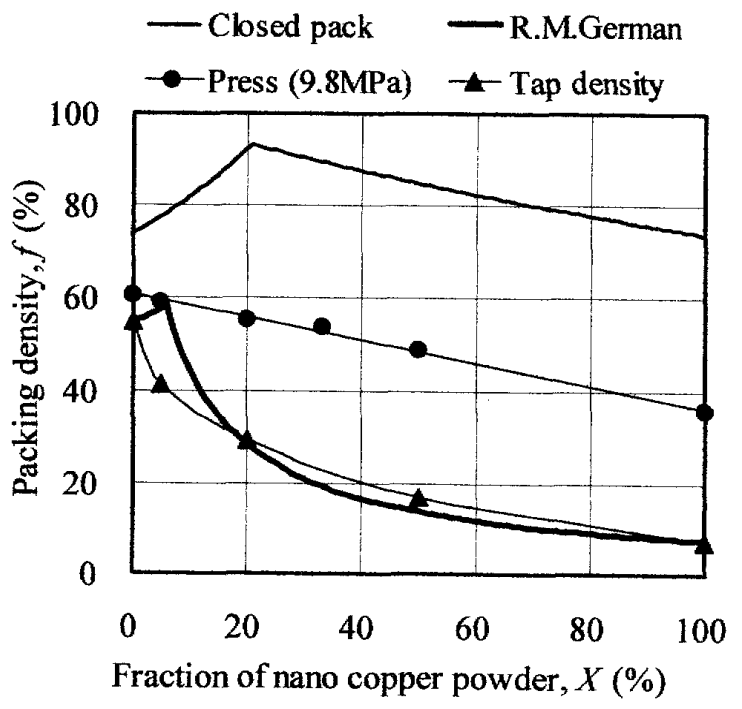

Fig. 3 Packing density of hybrid copper powders with various mixing volume fractions 
密度の実測値より求めた充填摔にはピークが見られな かった。これはナノ銅粉は凝集しやすいため，数\%程 度のナノ銅粉を分散させて高密度に充填したマイクロ 銅粉の隙間に配置していないためであると考えられる。

\section{$2 \cdot 3$ パインダの四合割合の决定方法 現状の}

MIM $の$ 量産では，バインダ量を種々変化させて MIM 材料を調製し，種々の射出成形条件で成形体を作製し， 脱脂およひ涍結後の品質を評価して, MIM 材料の射出 成形後の成形体のバインダ体積から適切なバインダ量 を試行錯誤的に決定されることが多い，本研究では， 高価な十ノ銅粉を少量で実験を行なう必要性から, 2・ 2 項で得られたハイブリッド銅粉の充填率の結果を用 いて，バインタ配合割合を決定する方法を検討した。

MIM 材料を調製子る際に必要なバインダ配合割合

(V) は，十ノ銅粉割合の異なるハイブリッド銅粉に 含まれる空隙率 $(P)$ を銅粉のタップ密度 $\left(\varphi_{T \text { Tqp }}\right)$ と純 銅の真密度 $\left(\rho_{\text {Tne }}\right)$ から算出し。これを変数として式(5) により定義した.

$$
V=A \cdot P \times 100=A \cdot\left(1-\rho_{\text {Tap }} / \rho_{\text {True }}\right) \times 100 \cdots
$$

ここで, バインダ係数 $(A)$ は MIM 材料の溶融粘度を 支配し, MIM プロセスの射出成形時の流動性に影響を 及ぼす重要な係数であり，粉末の形状や凝集など粒子 閒のすべりの程度により変化する. 式(5)では，ハイブ リッド銅粉に含まれる空陌率 $(P)$ を銅粉のタップ密 度 $\left(\rho_{\text {Tap }}\right)$ から算出しているため, 射出成形時の圧力に よる氏粉度を考慮していない。ゆえに，バインダ係数 が $A=1$ の場合は粉末の空隙率に相等する多量のバイン ダか配合されることになるため, MIM の粘度は非常に 低くなるが，脱脂後の粉末の密度が低く，緻密な焼結 体が得られない。そこで, MIM の量産に使用されてい るマイクロ銅粉のみ $(X=0 \%)$ で調製された MIM 材料

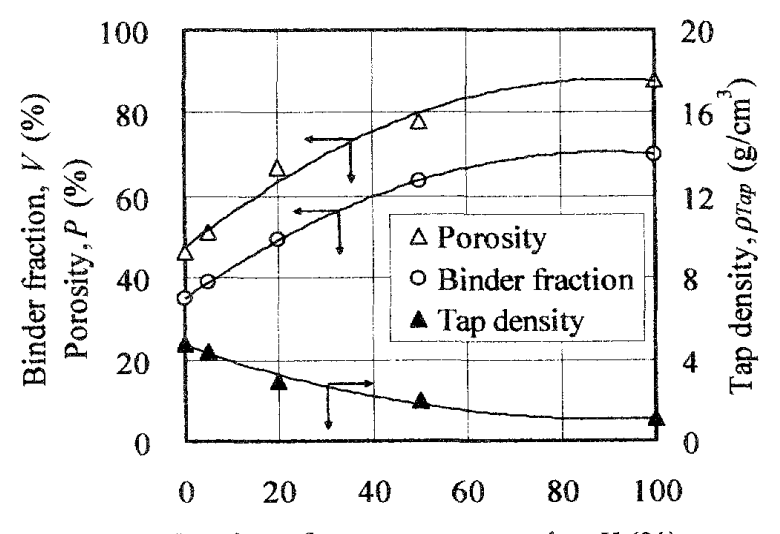

Fraction of nano copper powder, $X(\%)$

Fig. 4 Binder fraction of MIM feedstock, porosity and tap density of hybrid powders with various mixing fractions
のバインダ配合割合が既知 $(V=35 \%)$ であるため, こ れを基準に，式(5)よりバインダ係数 $A=0.775$ を求め, この係数を用いてハイブリッド銅粉で調製される MIM材料のバインダ量(り)を図4のように決定した。 この図より，ナノ銅粉割合 $(X)$ の増加に伴い，バイ ンダ量 (V) は $X=50 \%$ まで急激に増加し， $X=50 \%$ 以上 では緩慢な増加傾问であることが分かる。

2-4 試検片およひ製造方法 図5に示寸ような 小型ダンベル試験片を射出成形により作製した．金型 寸法で幅 $1 \mathrm{~mm}$ ，厚さ $1 \mathrm{~mm}$ の狭小な平行部および両端 に2.5mmの円盤の掴み部を有寸る形状である.

本研究で用いた微量混練射出成形機は，図 6(a) 亿示 すような堅型の卓上サイズ（高さ $859 \mathrm{~mm}$, シリンダ圧 $0.8 \mathrm{MPa}$ ) である. 原料の混練は，図 6(b)に示少ように 混練槽に金属粉末およびバインダを投入し，プランジ 中を回転させて行う．射出成形は，図 6(c)に示すよう に本体上部に設置したエアシリンダに圧縮空気を送り， プランジャを突き出して, MIM 材料を金型のキャビテ イ内人高速で充填することにより行う。本機㵊小射 出容量が $0.05 \mathrm{cc}$ 之微量で，1 つの成形体に相等する量 で混練およひ射出成形が可能であるため，ショット間 の計量偏差が小さく成形体密度の偏差を低く抑えられ ることに加え，高価なナノ粉末の検討にも適している.

上述の方法により得られた成形体は，工業用脱脂焼 結炉（島津メクテム懒，VHSgr，40/40/100-M）を用い て, 大気中 $400^{\circ} \mathrm{C}$ で $2 \mathrm{hr}$ 加熱脱脂後，引き続き同炉で $\mathrm{H}_{2}$ および $\mathrm{Ar}$ 雾囲気中で $2 \mathrm{hr}$ 燒結を行った. 焼結温度 は $800^{\circ} \mathrm{C}, 900^{\circ} \mathrm{C}$ および $960^{\circ} \mathrm{C}$ に変化させた。

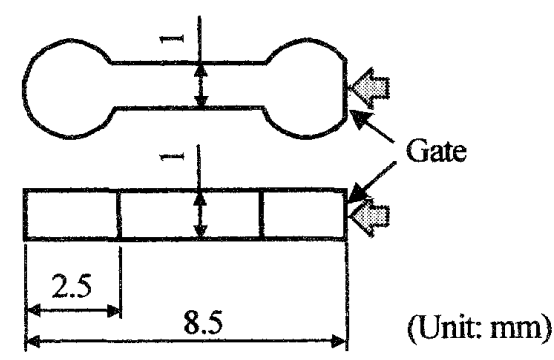

Fig. 5 Geometry of small dumbbell specimen

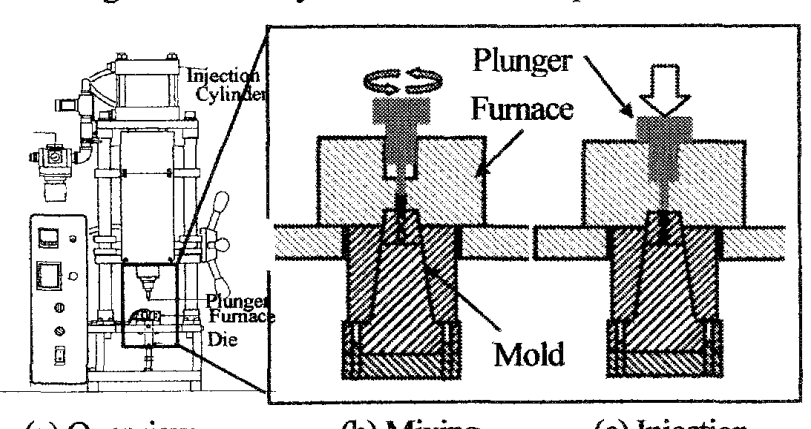

(a) Overview

(b) Mixing

(c) Injection

Fig. 6 Direct mixing-injection molding machine 
2-5 評俩方法 ナノ銅粉割合を種々変化させて 調製した MIM 材料 (容量 $100 \mathrm{~cm}^{3}$ ) を $1 \mathrm{hr}$ 混練した後, キャピログラフ（侏東洋精機製作所製）でせん断速度 を 5 500 mm/s に変化させ, $180^{\circ} \mathrm{C}$ での溶融粘度を測 定した. ナノ銅粉割合および焼結温度を種々変化させ て得られた焼結体の品質を評価するため，上皿電子天 科（珠A\&D, GR202，最小読み $0.01 \mathrm{mg}$ ）を用いてアル キメデス法により焼結体の密度を測定し，また燒結体 表面の SEM（日本電子怢，JSM-6380LA）観察より結晶 粒径を求めた. さらに超深度形状測定影微鏡（キーエ ンス(侏，VK-8500）で焼結体表面の平均表面粗さ $\left(R_{a}\right)$ を測定し，万能試験機（島津製作所，Auto Graph $\mathrm{AD}-10 \mathrm{TD})$ を用いてクロスヘッド速度 $5 \mathrm{~mm} / \mathrm{min}$ で焼 結体の引張試験を実施した.

\section{3. 実検結果および孝察}

3-1 MIM 村料の流動性 ナノ銅粉割合の異な る MIM 材料の溶融粘度測定の結果を図 7 に示す。 せ 儿断速度が大きいほど MIM 材料の溶融粘度は低下す る傾向を示したが，どのせん断速度においてもナノ銅 粉を 5\%添加すると溶融粘度は大きく低下した。これ はナノ銅粉の添加により，マイク口銅粉間にナノ銅粉 が入り込み，マイクロ銅粉間の抵抗が減少し，流動性 が向上したと考えられる.さらにナノ銅粉を $20 \%$ 以上 添加しても溶融粘度はあまり変化せず，ナノ銅粉割合 $100 \% の 5 \mathrm{~mm} / \mathrm{s}$ の場合を除いてほぼ一定の值を示した. これは，ナノ銅粉割合の増加に伴う抵抗増に応じてバ インダ量を増加させたことに起因していると思われる。

\section{3-2 烧結体の密度およひ組織 ナノ銅粉割合の} 異なる MIM 材料で作製された燅結体の相対密度を図 8 に示寸. 焼結温度が高いほど焼結体の相対密度は高 くなるという一般的な傾向が見られた. マイクロ銅粉 $100 \%$ MIM 材料から作製された焼結体の相対密度は 98\%以上の高い值が得られているのに対して，十銅 粉 100\%の場合は 92〜94\%でかなり低い值であった. ナノ銅粉割合が 20\%まで増加すると相対密度は低下す る傾向を示し，ナノ銅粉割合が $20 \%$ 以上ではナノ銅粉

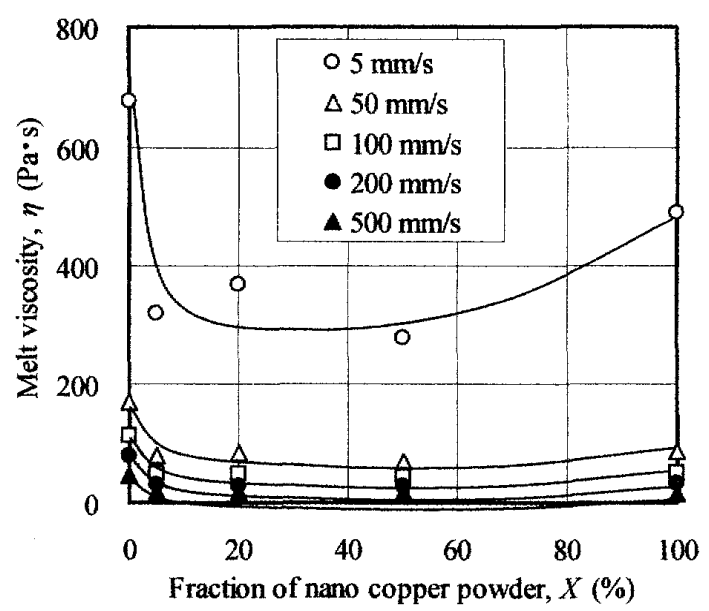

Fig. 7 Melt viscosity of MIM feedstock with various mixing volume fractions

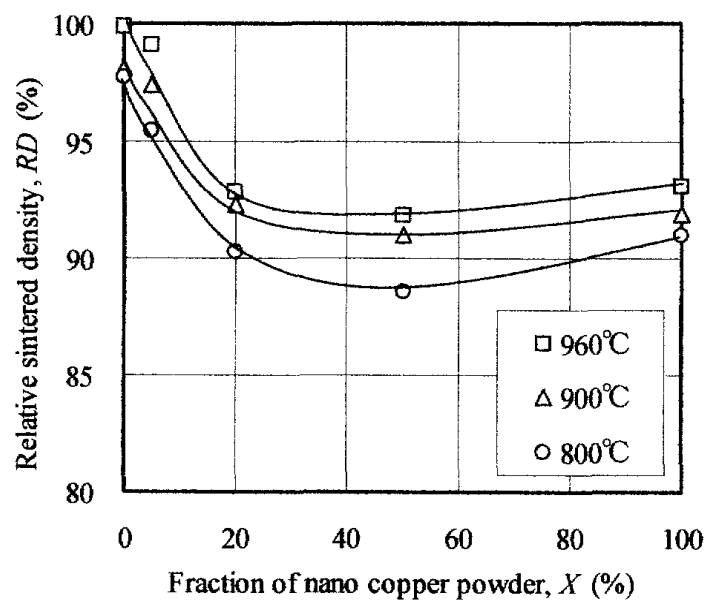

Fig. 8 Relative density of sintered parts with various mixing volume fractions

100\%の相対密度と大きな差異は見られなかった。

焼結体の断面観察を行った結果を図 9 に示寸。十，

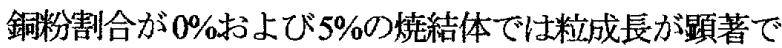
あり，大きな気孔は見られなかった。一方，ナノ銅粉 割合が $20 \%$ の焼結体では気孔が粒界およひ粒内に多数 存在し，ナノ銅粉割合が 100\%の焼結体では非常に細 かい粒界に多数の気孔が見られた. 酸化の著しいナ， 銅粉の添加により焼結が不十.分なため気孔が発生し， 焼結体の相対密度を低下させたことが分かった。

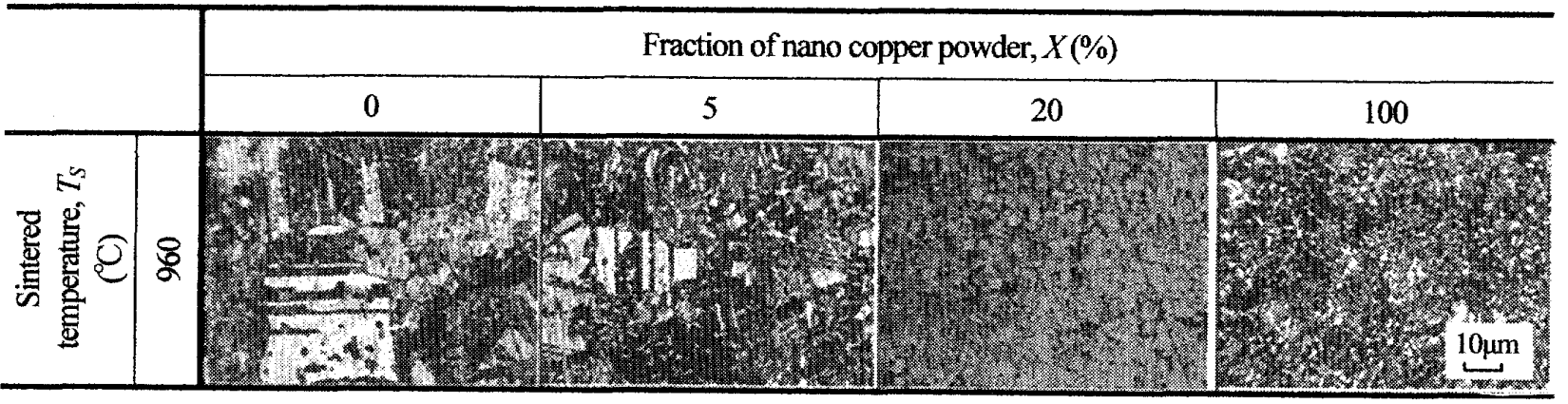

Fig. 9 SEM images on cross-sections of sintered compacts 


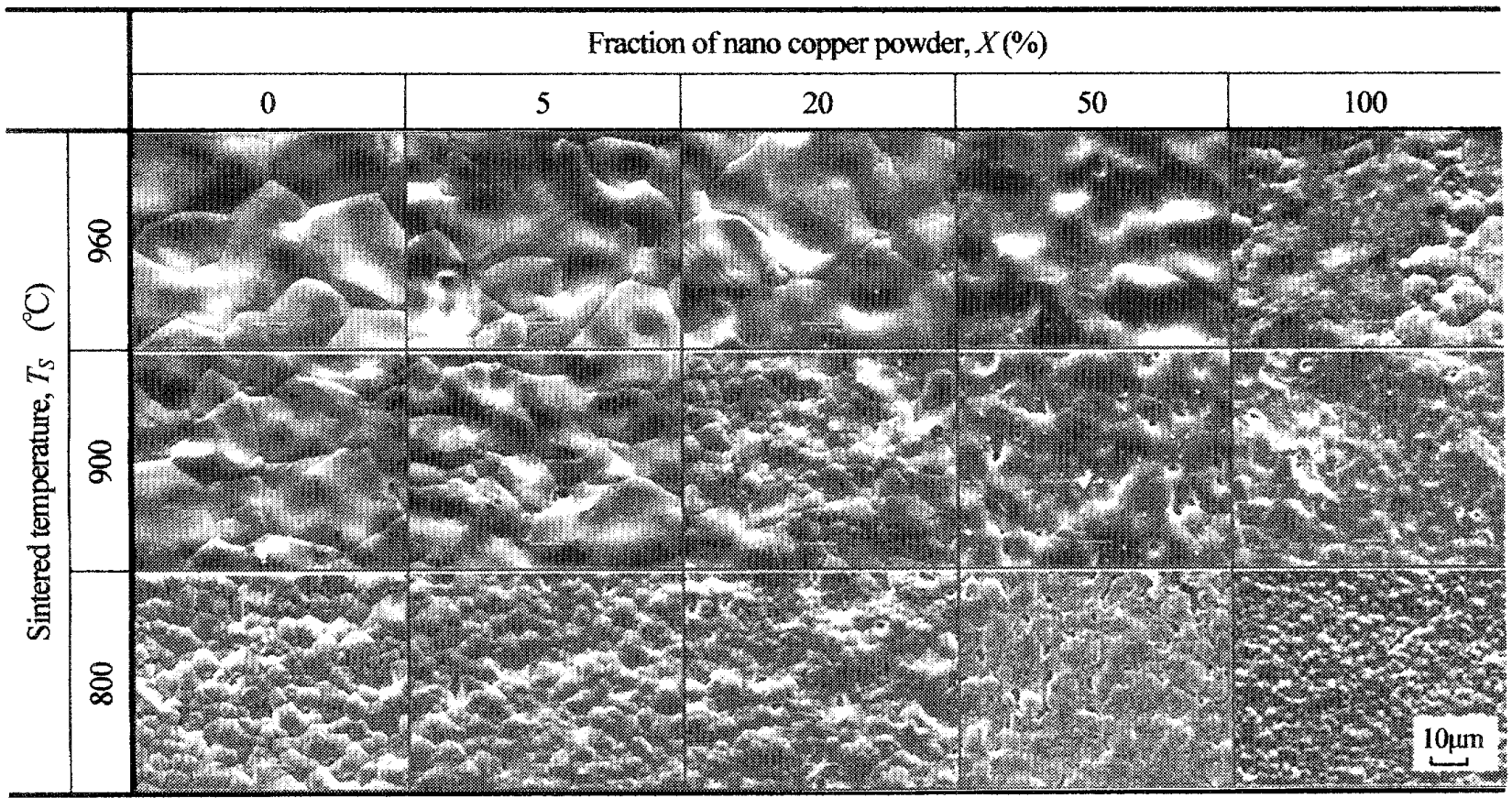

Fig.10 SEM images on the surfaces of sintered compacts for various temperatures and fractions of nano copper powder

3 -3 嫃結体の結晶粒经ナノ鋼粉割合の異な るMIM材料を用いて作製した焼結体表面のSEM像 を図 10 に示守。また，上記のSEM像から求めた結 晶粒径の結果を図 11 に示守。図 10 より，焼結温度 が高いほど，焼結体の結晶粒は大きく成長している ことが明らかである。焼結温度 $800^{\circ} \mathrm{C}$ のイクロ銅 粉 $100 \%$ とナノ銅粉 $100 \%$ の焼結体の組織を比較する と，ナノ銅粉 $100 \%$ の焼結体の結晶粒は極めて小さ いことが分かる．図11より，焼結温度が高いほど， ハイブリッド粉末の結晶粒径は大きくなる傾向が見

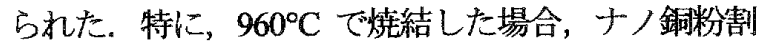
合が 50\%の燒結体の結唱粒徍は, マイクロ銅粉 100\% およびナノ銅粉 $100 \%$ の場合よりも約 3 倍大きい。

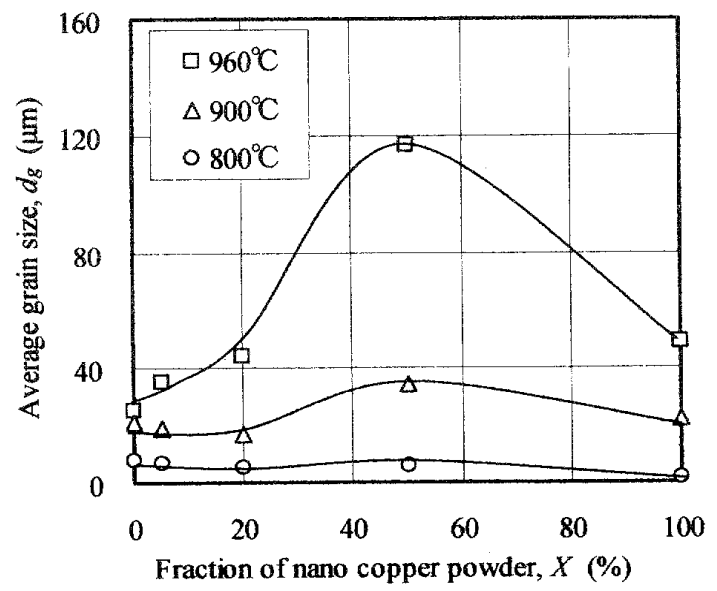

Fig.11 Average grain size of sintered parts with various mixing volume fractions
3.4 焼結体の表面粗さ ナノ銅粉割合の巽な る MIM 材料を用いて作製した燒結体の表面粗さの 測定結果を図 12 に示寸。焼結温度が高いほど, 焼結 体の表面粗さは小さくなる傾向を示した．これは試 験片表面が高温にさらされることにより焼結性が向 上し，表層部にある気孔が消滅したためであると思 われる。しかし，ナノ銅粉割合が $50 \%$ まではナノ銅 粉の添加量に忍じて表面粗さは増加した。これは， 図4で示したようにナノ銅粉割合の増加とともに増 加したバインダが脱脂により消失したため，銅粉木 の移動が大きくなり変形が生じ, 表面粗さが増加し たと考えられる。特に，ナノ銅粉割合が $50 \%$ の場合 はバインダ割合が高いことに加え，結晶粒成長が著

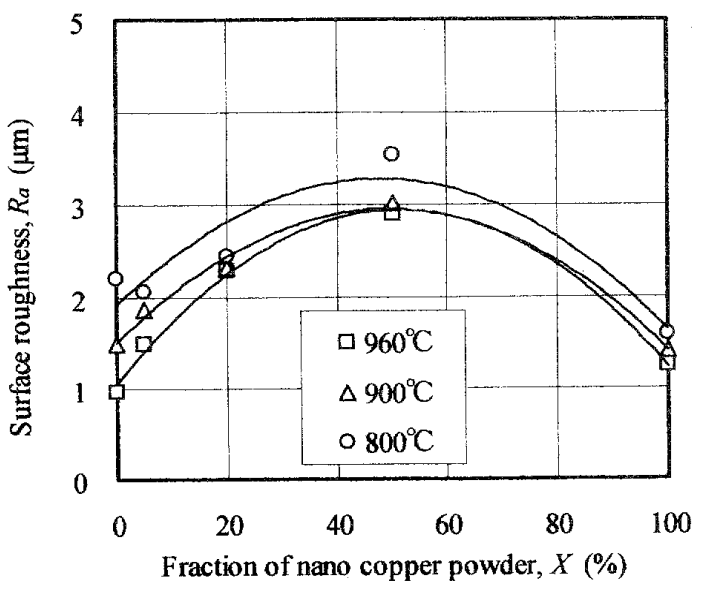

Fig.12 Surface roughness of sintered parts with various mixing volume fractions 
しいため，その影響が顥著になったと考えられる. 一方,ナノ銅粉割合が $100 \%$ の場合は, 粒径がサブ $\mu \mathrm{m}$ サイズの超微粒子を使用したにもかかわらず，表面 粗さに顕著な改善は見られず，マイクロ銅粉割合が $100 \%$ の場合の表面粗さとほぼ同等の $R_{a}=1.5 \mu \mathrm{m}$ であ った.これは，ナノ銅粉が凝集しやすく，一次粒子 径よりも大きくなるためであると考えられる.

\section{5 烧結体の引張強さ ナノ銅粉割合の異な} る MIM 材料を用いて作製した焼結体の引張試験結 果を図 13 に示す.ナノ銅粉割合の增加とともに，引 張強さはほぼ比例的に低下する傾向を示した. 図 9 の焼結体の相対密度の結果では，ナノ銅粉割合が 20\%まで低下し，20\%以上ではほぼ一定であるのに 対して, 引張強さはナノ銅粉割合が $20 \%$ 以上でも低 下しており，相対密度の結果とは傾向が異なってい る.一方, 図 11 の結晶粒径の結果では, ナノ銅粉割 合が $50 \%$ まで結晶粓が粗大化し, $100 \%$ では結晶粒は 小さいため，ナノ銅粉割合が $100 \%$ 強度低下は結 晶粒粗大化による影響ではないと言える.さらに, 図 13 では, 焼結温度が高いほど引張強さは明確に高 いという緻密化の効果も得られていない. それゆえ， 相対密度と結晶粒径, および引張試験の3 つの結果 から判断して，上述のナノ銅粉の添加による強度低 下の理由は，焼結体の密度低下および結晶粒粗大化 による影響以外に，焼結体の残炭量が関与している と思われる. 図 4 で既述したように，ナノ銅粉割合 が増加するとバインタ配合割合を増加させる必要が あり，そのため燒結体の残炭量が増加し，燒結を阻 害し, 強度低下を引き起こしたと推察される.ナノ 銅粉割合および焼結条件の違いが焼結体の残炭量に 及ぼす影響を明らかにし，強度の向上が今後の課題 である.

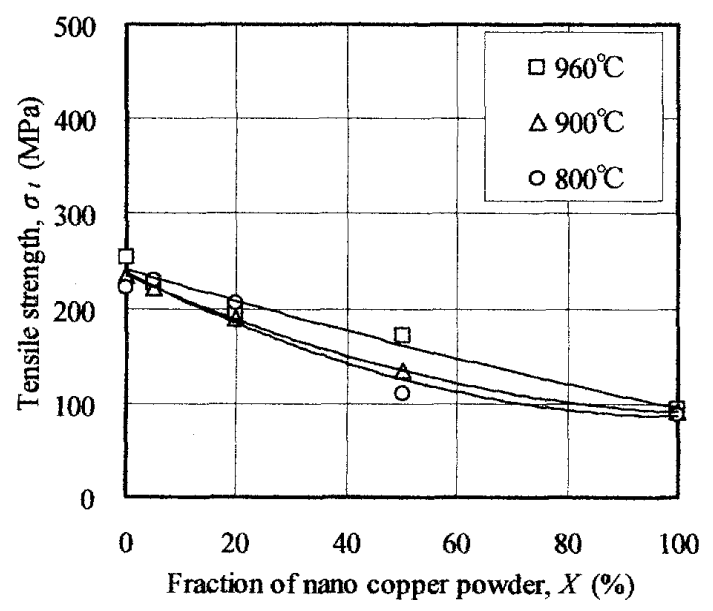

Fig.13 Tensile strength of sintered parts with various mixing volume fractions

\section{4. 結言}

本研究では，ナノ銅粉とマイクロ銅粉を組み合わ せたハイブリッド粉末を用いて調製した MIM 材料 の溶融粘度について調查し，それらの MIM 材料を 用いて微量混練射出成形機により小型ダンベル試験 片を成形した。 この焼結体の密度, 結晶粓径, 表面 粗さおよび引張強さに及ぼす焼結温度や十ノ銅粉割 合の影響を調查した結果, 以下の知見が得られた。

(1) MIM 材料の溶融粘度は，ナノ銅粉を $5 \%$ 添加寸 ると著しく低下するが，ナノ銅粉を 20〜50\%程 度添加するとバインダ量の配合割合が高くなる にもかかわらず，あまり変化しない，

(2) 焼結体の相対密度は, ナノ銅粉を $20 \%$ まで添加 すると 90 数\%まで低下するが, ナノ銅粉を $20 \%$ 以上添加しても変化せず，ほぼ一定である.

(3) 焼結体の結晶粒径は，焼結温度が高いほど大き く, ナノ銅粉を 50\%まで添加すると増大するが， マイクロ銅粉またはナノ銅粉が $100 \%$ 場合は 同程度で小さく, 焼結温度が低い場合はナノ銅 粉割合に依らず, 結晶粒径は約 $10 \mu \mathrm{m}$ 以下である.

（4）焼結体の表面粗さは，十ノ銅粉を添加すると增 大寸る傾向にあるが，マイクロ銅粉およびナノ 銅粉がどちらも $100 \%$ の場合は同程度である.

（5）焼結体の引張強さは，ナノ銅粉割合の増加とと もにほぼ比例的に低下寸る。

\section{文献}

(1) Miura H., Takagi K. (Joint translators), German R.M. (Author), Science of Powder Metallurgy (In Japanese), Utidaroukakuho (1996).

(2) German R.M., Bose A., Injection Molding of Metals and Ceramics, MPIF (1997).

(3) Osada T., Nishiyabu K., Matsuzaki S., Tanaka S.,

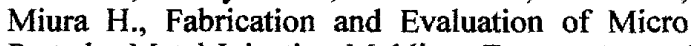
Parts by Metal Injection Molding, Transactions of the Japan Society of Mechanical Engineers, Series $A$, Vol. 70, No.698 (2004), pp.1522-1528.

(4) Matsuzaki S., Tanaka S., Nishiyabu K., Micro-reactor Technology, NTS Inc., (2005) pp. 287-296.

(5) Matsuzaki S., Tanaka S., Nishiyabu K., Fabrication Method of Micro Structured Parts by Metal Injection Molding with LIGA Process, Journal of the Japan Society of Powder and Powder Metallurgy, Vol.52, No.1, (2005) pp.55-59.

(6) Nishiyabu K., Basics of Powder Compaction and Material Processing III : Recent Advance in Metal Powder Injection Molding, Lecture, Journal of the Japan Society of Materials Science, Vol.58, No.1, (2009) pp.87-92.

(7) German R.M., Prediction of Sintered Density for Bimodal Powder Mixtures, Metallurgical Transactions $A$, (1992) 